\title{
Kitchen Resources, School Location and Academic Achievement of SS2 Chemistry Students.
}

\author{
Nja Cecilia Obi, Neji Hope Amba \\ Department of Curriculum and Teaching University of Calabar P.M.B.1115 Calabar. Cross River State Nigeria \\ Department of Curriculum and teaching University of Calabar, P.M.M. Calabar. Cross River State Nigeria.
}

\begin{abstract}
This research work examined the use of kitchen resources in the teaching of Thermochemistry to SS2 Chemistry students in rural and urban schools. Kitchen resources were used to perform experiments; fermentation of five sample of fruit juices, heating capacities of five samples of wood, induced thermal decomposition of five samples of shellfish shell powder and dissolution of five samples of glucose. A total of 100 senior secondary two chemistry students were involved in the study. There were 60 males and 40 females from two secondary schools in Ikom Local Government Areas in Cross River State, Nigeria. A pre-test post-test design was used for the study. Chemistry Achievement Test (Cat) was used to collect data for the study Kinder Richardson Formula 21 was used to establish reliability of Cat. The result gave a reliability coefficient of 0.84 . Analysis of covariance and descriptive statistics was used for data analysis. Findings showed a non-significant difference in relation to school location and gender. It was recommended that teachers be innovative and resourceful using materials in the kitchen to teach as resources in Chemistry classes.This is so as location does not affect learning but materials used in teaching.
\end{abstract}

\section{Background of study}

In every given society, education is very important. This education, be it formal or informal is very necessary for transmission of societal norms and values. Studies have found that the locality of the school in rural or urban materials used in teaching, functioning laboratories among others are all school locational variables that significantly affect academic performance of students (Adewuyi, 2002; Ahmed, 2003; and Ijeoma, 2007).

Academic performance in this context refers to the ability of chemistry students to pass all exams be it internal or external with at least a credit pass. Academic performance in Ikom Education Zone in particular and Nigeria as a whole has witnessed a deplorable state in academic achievement.

There is a problem of dearth in science resources and this contributes to students' poor academic performance in chemistry at the secondary level (Ifeakor, 2006). First, that learning is not meant to be a passive activity which targets only the mental information students receive. Students learn best when they are able to combine physical activity with mental activity. Too often in classrooms teachers restrict their students to long periods of sitting still which is not only boring but actually works against effective learning (caine and caine). Chemistry is a science subject and has been stipulated to be taught using activity (Ifeakor, 2006) in schools. Teachers do not comply accordingly. The most commonly cited reason is lack of science equipment in schools. Although efforts appear to be made in building science equipments in schools it has not matched demands of schools in any satisfactorily manner (Oriade, 2008).

Since the problem of equipping schools with materials and apparatuses is enormous and the absence of these facilities appears to adversely affect the teaching and learning of Chemistry. Some measures need to be taken. The kitchen is stocked with quality materials and is most likely the best chemical laboratory in the world (Hayward, 1992). Many materials and activities abound in the kitchen.

In the absence of standard acid, base and indicator for a titration experiments, materials in the kitchen can be used as resources to teach titration. Juice from unripe fruits will serve as acid, ashes of roasted plantain peels dissolved in water and filtered can be used as base, red cabbage can be used as indicator. Activities taking place in refrigerators can be used to teach change of state. Boiling of water can be used to teach change of state. Disappearance of camphor ball can be used to teach sublimation.

Elders in the villages and towns d often practice Chemistry in the kitchen but there is no formal use of resources in the kitchen in a chemistry laboratory. It is based. on this that the researcher attempted to find out how student learn when taught using kitchen resources.

The zip code in which a child grows up affects much more than their mailing address (Berliner, 2005), where a child lives indirectly influences the type and quality of education that he or she receives.Students' achievement is greatly affected by the area in which a student lives because of variation in resources, quality of teachers and not necessarily the name of the place.

Historically, rural areas have lagged behind urban and suburban schools in educational achievement. National Education Association (Brown \& Swanson 2001). Some rural schools are thriving due to small size 
and closeness to the community while others are failing by providing their students with a mediocre education, from lack of resources and teachers (Rural Education, 2013).

From literature reviewed so far, there is disparity in academic performance of students because resources used in teaching differs. This study therefore seeks to teach both rural and urban schools Chemistry using kitchen resources which are found both in urban and rural setting.

\section{Statement of problem}

Emphasizing the importance of kitchen resources to high academic achievement of students in both rural and urban school is worth investigating as intelligence is not based on where you live but what you interact with (Brain base learning, 2013). Research on use of kitchen resources was mainly assertions and no empirical setting especially in Nigeria in general and Ikom Education Zone specifically.

\section{Objectives of the study}

i. To examine the relationship of school location and academic achievement of students when taught using kitchen resources.

ii. To examine how gender affect students performance of students when taught using kitchen resources in urban and rural school.

\section{Research questions}

i. Is there any relationship between school location and academic achievement of students when taught using kitchen resources?

ii. What effect does gender have on rural and urban school when taught using kitchen resources?

\section{Research hypothesis}

i. There is no significant difference between school location and academic achievement of students when taught using kitchen resources.

ii. There is no significant difference gender and academic achievement of students with regard to school location when taught using kitchen resources.

\section{Significant of study}

It is hoped that this study will provide information to educators, teachers and administrators to reflect upon kitchen resources in the absence of standard materials.

\section{Materials and methods}

The research made use of pre-test-post-test control group design. Chemistry Achievement Test (Cat) was the instrument that was used for the study. It was a 25 -item four-option objective test. This served for pretest and post-test. Cat had reliability of 0.84 . Students in both rural and urban schools were taught using identified researchers kitchen resources.

\section{Experiments carried out by rural and urban school}

\begin{tabular}{|l|l|l|}
\hline Enthalpy change & Type of reaction & Experiments \\
\hline Heat of formation & Exothermic & Fermentation of fruits \\
\hline Heat of combustion & Exothermic & Burning of firewood \\
\hline Heat of solution & Endothermic & Dissolution of glucose \\
\hline Heat of formation & Endothermic & $\begin{array}{l}\text { Decomposition of shellfish shell } \\
\text { powder }\end{array}$ \\
\hline
\end{tabular}

Before teaching, Cat was administered and at the end of four weeks of teaching Cat was readministered. The data collected were analyzed using descriptive statistics and analysis of covariance using pretest scores as covariates. 
Table 1: Descriptive statistics and 2 x 2 analysis of covariance of SS2 Chemistry students classified by location and gender

\begin{tabular}{|l|l|l|l|l|l|l|}
\hline Variable & Group & Sample size & Mean & $\begin{array}{l}\text { Pre-test standard } \\
\text { deviation }\end{array}$ & $\begin{array}{l}\text { Post-test } \\
\text { mean }\end{array}$ & Deviation \\
\hline $\begin{array}{l}\text { School } \\
\text { location }\end{array}$ & Rural & 48 & 3.96 & 1.29 & 11.15 & 4.48 \\
\hline & Urban & 52 & 3.52 & 1.93 & 11.58 & 5.21 \\
\hline \multirow{3}{*}{ Gender } & Male & 60 & 3.45 & 1.41 & 11.48 & 4.65 \\
\cline { 2 - 7 } & Female & 40 & 4.15 & 1.92 & 11.18 & 5.19 \\
\hline & All & 100 & 3.73 & 1.69 & 11.36 & 4.92 \\
\hline
\end{tabular}

\begin{tabular}{|l|l|l|l|l|l|l|}
\hline Sources of variation & $\begin{array}{l}\text { Sum of } \\
\text { squares }\end{array}$ & $\mathrm{df}$ & $\begin{array}{l}\text { Mean } \\
\text { square }\end{array}$ & $\mathrm{F}$ & Significant of F & $\begin{array}{l}\text { Decision at } \\
0.05\end{array}$ \\
\hline Covariates (pre-test) & 1650.749 & 1 & 1650.749 & 338.895 & .000 & .005 \\
\hline Main effects & 241.525 & 2 & 80.508 & 3.663 & .015 & $\mathrm{NS}$ \\
\hline Location & 15,717 & 1 & 15.717 & .715 & .400 & $\mathrm{NS}$ \\
\hline 2-way interactions & 33.533 & 2 & 11.178 & .509 & .677 & $\mathrm{NS}$ \\
\hline Location Vs Treat & 9.120 & 1 & 9.120 & .415 & .521 & $\mathrm{NS}$ \\
\hline Gen Vs location & 21.854 & 1 & 21.854 & .994 & .321 & $\mathrm{NS}$ \\
\hline Explained & 308.815 & 6 & 44.116 & 2.007 & 1062 & $\mathrm{NS}$ \\
\hline Residual & 2022.225 & 92 & 21.989 & & & \\
\hline Total & 2331.040 & 99 & 23.546 & & & \\
\hline
\end{tabular}

The result of Table 1 was considered at confidence level of $95 \%$, . A consideration of the means of the pre-test and post-test of location (rural and urban) showed, 3.52, 3.96, 11.15 and 11.58 respectively. There was also a deviation of the pre-test and post-test scores of gender groups (male \& female). The mean scores of pre-test and post-test scores of male students were 3.45 and 11.48 respectively whereas the means scores for the female students pre-test and post-test were 4.15 and 11.18 respectively. Base on the observation from descriptive statistics analysis of covariance was used to determine the observed differences of the post-test and to ascertain the extent of significance.

\section{Hypothesis 1:}

There is no significant difference between the academic performance of SS2 chemistry students in rural and urban school when taught using kitchen resources.

As shown in Table I, the 2-way interaction between teaching with kitchen resources and school location (rural or urban) was not significant $0.521<0.05$ probability levels used. This implies that school location did not affect students' performance in Thermochemistry when taught using kitchen resources. The null hypothesis was accepted.

\section{Hypothesis 2:}

There is no significant difference between the performance of male and female SS2 chemistry students in rural and urban school taught Thermochemistry using kitchen resources. As shown in Table 1, the 2 way interaction between teaching with kitchen resources and gender in both rural and urban school was not significant $(0.947<0.05)$. This implies that teaching with kitchen resources does not significantly affect he academic performance of students in respect to gender (male \& female).

\section{Discussion of results}

Effect of school location (rural or urban) on the academic performance of students when taught Thermochemistry using kitchen resources. This implies that both rural and urban schools gained equally from using kitchen resources to teach Thermochemistry. Studies have shown that rural and urban residents relate differently to educational achievement (Rodney \& Hamilton, 2000 and Williams, 2005). Particularly, these studies indicated that urban residents were almost always better educated than rural residents, regardless of age, sex, maturity or percentage. Such study affirms that there exists interplay of learning process and learning environment, which is directly related to where the school is situated. The environmental resources can therefore make or mar an individual's performance in learning. Abdullahi, 1992 noted that science environments which includes resources used in teaching is an indispensable factor for the understanding of concepts, principles and 
application of knowledge. This implies that it is not just the location that affects students' academic performance but absence of basic resources for teaching and learning. Reeves, (2005) studied the effect of school location on science and mathematics achievement trends. The findings revealed that rural location do not significantly influence the achievement trends of $5^{\text {th }}$ grade, mathematics and $12^{\text {th }}$ grade Chemistry. Where ever a student resides, when the necessary materials example kitchen resources that are found in the child location is used to teach, the students will understand the concept very well since intelligence is not based on where one stays.

Effect of gender on student's academic performance taught using kitchen resources.

Table 1 showed a non-significant difference in the academic performance of SS2 male and female students when taught using kitchen resources $(0.94>0.05)$.

The studies of Nsofor (2001), Nwosu (2001) revealed that both male and female students could do well in science if exposed to similar learning conditions. Gender does not significantly affect students learning as intelligence is not sex dependant.

\section{Summary}

The study sought to find out how students in rural and urban school learn when expose to the same learning situation of kitchen resources. Kitchen resources were materials identified in the kitchen by the researcher that were used to conduct experiments and teach Thermochemistry. Chemistry students in rural and urban schools were taught using kitchen resources. The results of cat were collected and analyzed. Analyses showed that both rural and urban school gained from the use of kitchen resources and the analysis showed a non-significant difference. The study also sought to find out how male and female students learn when taught using kitchen resources. The result was also not significant as intelligence was not dependant on sex but on how and what materials are presented to learners.

\section{Recommendation}

Teachers are advised to try as much as possible to ascertain what the learner already know and teach accordingly by using kitchen resources that learners are already use to. Teachers are expected to be resourceful.

\section{References}

[1] Abdullahi, A. (1992). An investigation into the status of primary science in Nigeria, Journal of Science Teachers Association of Nigeria. 20(2), 193-195.

[2] Adewuyi, D. A.(2002).Comparison between school effectiveness characteristics and classroom instruction strategies in the United States and Nigeria. Africa Development,27 (!and2):263-287

[3] Amed, T. M.(2003). Education and national development in Nigeria. Journal of studies in Education 10:35-46

[4] Berliner, D. C. (2005). Our impoverished view of educational reform: Presidential invited speech to the American Educational Research Association Meeting in Montreal Canada.

[5] Brown, D. L. (2003). Challenges for Rural America in the $21^{\text {st }}$ century. University Park, P. A: Pennsylvania State University Press.

[6] Caine,R and Caine, R. N (1994).Teaching and the human brain.

[7] Ifeakor, A. C.(2006). The status of resources for effective teaching of Chemistry in Nigeria Secondary Schools.STAN,205-207

[8] Ijeoma,M.E . (2007).Students' perception of their classroom environment. Lagos journal of Educattional Administration and Planning,3 (1):145-152.

[9] Nsofor, C. C. (2001). Cultural impediments on women in STM education.. STAN 63-68.

[10] Nwosu, J. A. (2001). Students task involvement and achievement in process oriented science activities. Science Education. 70, 1-72.

[11] Oriade, T. I. (2008).An empirical study of the utilization of instruction materials and laboratory resources in Biology curriculum implementation. STAN.

[12] Reeves, J. P. (2005). Learning science in the changing world: Cross National Studies of Science Achievement Australia: IEA Headquarters.

[13] Rodney, J. \& Hamilton, S. (2000). The study of science by high school students and environmental variable .Journal of Educational Research 72(3), 213-220.

[14] Rural Education (2013). University of Michigan downloaded from Internet 07-05-13.

[15] Williams, R. T. (2005). The teaching-learning environment in students centered physics classroom. .Journal of Research in Science Teaching._186(4) 258-265. 